\title{
ANALISIS FAKTOR-FAKTOR YANG MEMPENGARUHI KEBERHASILAN LELANG EKSEKUSI HAK TANGGUNGAN PADA KANTOR PELAYANAN KEKAYAAN NEGARA DAN LELANG PALU (2015 - SEPTEMBER 2016)
}

\author{
Agus Susanto, Tri Oldy Rotinsulu, George M.V. Kawung \\ Fakultas Ekonomi dan Bisnis, Magister Ilmu Ekonomi \\ Universitas Sam Ratulangi, Manado
}

\begin{abstract}
ABSTRAK
Penelitian ini bertujuan untuk mengetahui faktor-faktor yang mempengaruhi keberhasilan (laku terjual atau tidak laku terjual) lelang eksekusi hak tanggungan obyek property riil di KPKNL Palu. Penelitian ini penting dilakukan karena keberhasilan lelang eksekusi hak tanggungan di KPKNL Palu relatif rendah dan keberhasilan lelang secara langsung akan meningkatkan debt recovery serta penerimaan negara seperti bea lelang, pajak penghasilan pasal 25, dan BPHTB.Data yang diteliti berupa risalah lelang eksekusi hak tanggungan di KPKNL Palu yang terletak di Kota Palu dari tahun 2015 sampai dengan September 2016 dengan mengambil sampel sebanyak 200 transaksi lelang. Metode analisis yang digunakan adalah analisis berganda binari dengan menggunakan model logit.Hasil penelitian menunjukkan bahwa faktor faktor yang berpengaruh positif dan signifikan terhadap hasil lelang eksekusi hak tanggungan di KPKNL Palu adalah lokasi, aksesibilitas, penyelenggara pra lelang dan cara penawaran lelang.

Kata Kunci : Keberhasilan lelang eksekusi Hak Tanggungan, Hasil Lelang, Laku atau Tidak Laku terjual, Properti Riil

ABSTRACT

This study aims to determine the factors that influence the success (sold or not sold) mortgage auction of real property objects in KPKNL Palu. This research is important because the success of real property mortgage auction in KPKNL Palu relatively low and the success of the auction will directly will increase debt recovery and also state revenues such as auction fee, income tax and real estate tax.The data used in this research consist of real property mortgage auction in KPKNL Palu located in the city of Palu from 2015 until September 2016 by taking a sample of 200 transactions auction. The binary multiple regression method with logit model used to analysis in this researchThe result of this research show that significant factors influencing mortgage auction outcome in KPKNL Palu are location, accessibility, pre-auctioning houses and way bidding.
\end{abstract}

Keywords : Succesfull of Mortage Auctions, Auction Results, Sold or Unsold, Real Property 


\section{Latar Belakang}

\section{PENDAHULUAN}

Salah satu tujuan Negara Republik Indonesia sebagaimana tercantum dalam pembukaan Undang-Undang Dasar 1945 alinea keempat adalah untuk memajukan kesejahteraan umum. Untuk mewujudkan tujuan ini maka dilakukan pembangunan disegala bidang khususnya dibidang ekonomi. Pembangunan ekonomi harus didukung setiap komponen bangsa, salah satu di antaranya pelaku usaha, untuk itu dibutuhkan modal atau dana. Terkait kelancaran aktivitas ekonomi dan penyediaan dana inilah dunia perbankan berperan.

Sektor perbankan mempunyai peran mediasi, yaitu menghimpun dana dari pihak ketiga (nasabah) dan menyalurkan kembali dalam bentuk kredit kepada peminjam. Bank dituntut untuk menerapkan prinsip kehati-hatian (prudential banking) dalam menyalurkan kredit. Untuk mengantisipasi risiko kegagalan kredit, bank dapat mensyaratkan adanya jaminan kredit. Di samping jaminan pokok berupa barang dan atau usaha yang dibiayai dari kredit, bank juga dapat meminta jaminan tambahan berupa properti riil baik berupa tanah dan/atau bangunan.

Keberadaan kredit bermasalah dalam dunia perbankan merupakan kendala yang mengganggu dan mengancam sistem perbankan sehingga perlu perhatian yang serius. Adanya kredit macet berarti dana yang seharusnya bisa mengalir untuk mengembangkan sektor usaha lain menjadi tertahan sehingga akan mengganggu perekonomian secara umum. Cara penyelesaian kredit macet dengan menggunakan pendekatan hukum dan berpedoman pada ketentuan peraturan perundang-undangan yang berlaku dalam praktek perbankan.

Proses penyelesaian kredit macet dengan pendekatan hukum yang ada saat ini, alternatif penyelesaian dengan Undang-undang Hak Tanggungan (UUHT) khususnya pasal 6 merupakan proses yang singkat dan sederhana dengan biaya yang relatif murah dibandingkan pendekatan hukum lainnya. Hak tanggungan sebagaimana dimuat dalam pasal 1 ayat 1 UUHT adalah hak jaminan yang dibebankan pada hak atas tanah sebagaimana dimaksud dalam UU Nomor 5 Tahun 19960 tentang Peraturan Pokok-pokok Agraria, berikut atau tidak berikut benda-benda lain yang merupakan satu kesatuan dengan tanah itu, untuk pelunasan hutang tertentu yang memberikan kedudukan yang diutamakan kepada kreditor tertentu terhadap kreditor-kreditor lain. Meskipun UUHT telah berlaku sejak 01 April 1996 namun pelaksanaan lelang eksekusi hak tanggungan berdasarkan pasal 6 ini masih jauh dari harapan, meskipun frekuensi pelaksanaan lelang pasal 6 UUHT terus mengalami kenaikan. Anglin (2003: 11) menyatakan secara teoritis membuktikan ada bebarapa faktor yang mempengaruhi hasil lelang properti. Faktor-faktor tersebut adalah kondisi pasar dan mekanisme lelang yang meliputi harga dasar (limit) yang diumumkan oleh penjual.

Dalam penelitian ini akan dilakukan studi empiris mengenai faktor-faktor yang mempengaruhi keberhasilan lelang eksekusi hak tanggungan berdasarkan pasal 6 UUHT di Kantor Pelayanan Kekayaan Negara dan Lelang (KPKNL) Palu. KPKNL Palu adalah instansi vertikal Direktorat Jenderal Kekayaan Negara (DJKN) Kementerian Keuangan yang berwenang untuk melaksanakan lelang eksekusi Hak Tanggungan atas obyek lelang properti riil yang berada di wilayah kerjanya. Alasan pemilihan KPKNL Palu sebagai lokasi penelitian adalah kemudahan dalam memperoleh data dan karena tingginya frekuensi lelang hak tanggungan di KPKNL Palu. Penelitian ini penting dilakukan untuk mengetahui faktorfaktor yang mempengaruhi keberhasilan lelang eksekusi hak tanggungan di KPKNL Palu. Keberhasilan lelang yang dimaksud disini adalah properti yang dilelang laku terjual. KPKNL Palu dan pemohon lelang tentu mengharapkan tingkat keberhasilan lelang eksekusi hak tanggungan yang tinggi. Tingkat keberhasilan lelang di KPKNL Palu dalam dua tahun terakhir masih berada dibawah $10 \%$.

\section{Rumusan Masalah}

Berdasarkan latar belakang, dapat dirumuskan masalah dalam penulisan ini adalah sebagai berikut : 
1. Bagaimana pengaruh lokasi obyek properti riil yang terletak dekat dengan CBD terhadap keberhasilan lelang;

2. Bagaimana pengaruh aksesibilitas berupa lebar jalan menuju lokasi properti riil terhadap keberhasilan lelang;

3. Bagaimana pengaruh penyelenggara pralelang oleh balai lelang terhadap keberhasilan lelang;

4. Bagaimana pengaruh cara penawaran lelang melalui internet terhadap keberhasilan lelang.

\section{Tujuan Penelitian}

Berdasarkan rumusan masalah tersebut di atas telah diketahui uraian permasalahan dalam penulisan ini, sehingga dapat dirumuskan tujuan dalam penulisan ini adalah bagai berikut :

1. Menganalisis faktor lokasi yang mempengaruhi tingkat keberhasilan lelang eksekusi hak tanggungan.

2. Menganalisis faktor aksesibilitas yang mempengaruhi tingkat keberhasilan lelang eksekusi hak tanggungan.

3. Menganalisis faktor penyelenggara pralelang yang mempengaruhi tingkat keberhasilan lelang eksekusi hak tanggungan.

4. Menganalisis faktor cara penawaran lelang yang mempengaruhi tingkat keberhasilan lelang eksekusi hak tanggungan.

\section{Manfaat Penelitian}

Penelitian ini diharapkan dapat memberikan manfaat sebagai berikut:

1. Untuk memberikan gambaran mengenai faktor-faktor yang dominan mempengaruhi hasil lelang properti riil eksekusi hak tanggungan di KPKNL Palu;

2. Untuk menjadikan masukan pihak yang terkait dengan pelaksanaan lelang eksekusi hak tanggungan (kreditor/bank, balai lelang, KPKNL) dalam rangka meningkatkan keberhasilan lelang eksekusi hak tanggungan;

2. Untuk menambah khasanah ilmu pengetahuan terutama mengenai alternative transaksi jual beli properti riil;

3. Untuk memberikan gambaran bagi masyarakat luas mengenai penjualan properti riil jaminan hutang melalui mekanisme lelang eksekusi hak tanggungan

\section{Teori Pembangunan Ekonomi}

\section{LANDASAN TEORI}

Pembangunan adalah "suatu usaha pertumbuhan dan perubahan yang berencana dan dilakukan secara sadar oleh suatu bangsa, negara, dan pemerintah menuju modernitas dalam rangka pembinaan bangsa" Siagian (2005:9).

Pembangunan ekonomi adalah suatu proses saling berkaitan dan saling mempengaruhi antara faktor-faktor yang menghasilkan pembangunan ekonomi tersebut, dapat dilihat dan dianalisa pembangunan ekonomi tersebut bisa diketahui deretan peristiwa yang timbul dan akan mewujudkan peningkatan kegiatan ekonomi dan taraf kesejahtraan masyarakat berikutnya (Arsyad,1999:14-15). Menurut Arsyad, (1999:108-109) bahwa pembangunan ekonomi daerah adalah suatu proses dimana pemerintah daerah dan masyarakat mengelola sumber daya-sumber daya yang ada dan membentuk suatu pola kemitraan anatara pemerintah daerah dan sector swasta untuk menciptakan suatu lapangan kerja baru dan merangsang perkembangan kegiatan ekonomi(pertumbuhan ekonomi) diwilayah tersebut.

\section{Teori Properti}

Terdapat perbedaan pengertian antara real estat dan properti riil. Sesuai Standar Penilaian Indonesia 2007 (KPUP butir 3.1), real estat adalah benda fisik berwujud yang dapat dilihat dan disentuh, bersama-sama dengan segala sesuatu yang didirikan pada tanah yang bersangkutan, di atas atau di bawah tanah. Properti riil merupakan penguasaan yuridis atas tanah yang mencakup semua hak atas tanah, semua kepentingan, dan manfaat, 
yang berkaitan dengan kepemilikan real estat.

Sesuai definisi di atas, barang atau hak (Hak Milik, Hak Guna Bangunan, Hak Guna Usaha, dan Hak Pakai) yang menjadi obyek hak tanggungan termasuk dalam pengertian properti riil. Obyek hak tanggungan yang diharapkan laku terjual lelang tentunya mempunyai nilai. Nilai adalah konsep ekonomi yang merujuk kepada harga yang sangat mungkin disepakati oleh pembeli dan penjual dari suatu barang atau jasa yang tersedia untuk dibeli (SPI 2007:KPUP butir 4.5).

Hidayati dan Harjanto (2003: 19-23) menyatakan secara garis besar nilai suatu properti dipengaruhi oleh faktor permintaan dan penawaran, fisik, faktor lokasi dan perletakan, dan faktor kebangsaan/politik. Pertama, faktor permintaan dan penawaran dianggap sebagai satu faktor yang sangat luas dan menyeluruh dampaknya karena faktor ini meliputi faktor-faktor lainnya juga. Jika penawaran properti di pasaran tetap sedangkan permintaan bertambah, maka nilai properti akan naik, begitu pula sebaliknya. Dengan bertambahnya jumlah penduduk suatu kota atau wilayah secara otomatis akan menyebabkan bertambahnya permintaan properti. Faktor kedua yaitu faktor fisik properti meliputi jenis dan kegunaan properti, ukuran dan bentuk, serta desain dan konstruksi bangunan. Bentuk fisik properti juga tidak kurang peranannya dalam menentukan nilai sebuah properti, terutama sekali untuk tanah-tanah kosong dan tanah-tanah yang berpotensi dibangun. Faktor lokasi dapat dianggap sebagai faktor terkuat pengaruhnya terhadap nilai suatu properti. Secara umum "Teori Lokasi" menyatakan bahwa semakin jauh dari pusat kota maka nilainya akan semakin rendah.

\section{Lelang di Indonesia}

Berbeda dengan jual beli, lelang menurut pasal 1 Peraturan Lelang (Vendu Reglement) stb. 1908 Nomor 189 menyatakan bahwa lelang adalah "penjualan umum" yaitu penjualan barang-barang yang dilakukan kepada umum dengan harga penawaran yang meningkat atau menurun atau dengan pemasukan harga dalam sampul tertutup, atau kepada orang-orang yang diundang atau sebelumnya diberitahu mengenai pelelangan atau penjualan itu, atau dijinkan untuk ikut serta dan diberi kesempatan untuk menawar harga, menyetujui harga yang ditawarkan atau memasukkan harga dalam sampul tertutup. Pengertian lelang yang dipakai saat ini di Indonesia adalah sebagaimana diatur dalam Peraturan Lelang (Vendu Reglement) stb. 1908 Nomor 189 dan Instruksi Lelang (Vendu Instructie) stb. 1908 Nomor 190, berikut peraturan pelaksanaannya. Dalam Peraturan Menteri Keuangan Nomor : 27/PMK.06/2016 tentang petunjuk pelaksanaan lelang menyatakan bahwa yang dimaksud lelang adalah penjualan barang yang terbuka untuk umum dihadapan pejabat lelang, dengan cara penawaran harga secara tertulis dan/atau lisan yang semakin meningkat atau menurun untuk mencapai harga tertinggi yang didahului dengan pengumuman lelang.

Penjualan secara lelang wajib dilaksanakan oleh atau dihadapan Pejabat Lelang. Pejabat Lelang adalah pejabat umum yang diangkat oleh Menteri Keuangan untuk melaksanakan pelelangan berdasarkan peraturan perundang-undangan yang berlaku. Pejabat Lelang juga bertugas membuat risalah lelang yang merupakan laporan mengenai jalannya suatu pertemuan yang disusun secara teratur dan dapat dipertanggungjawabkan oleh si pembuat, sehingga mengikat sebagai dokumen resmi dari kejadian/peristiwa yang disebutkan di dalamnya. Sesuai ketentuan dalam Peraturan Menteri Keuangan Nomor 27/PMK.06/2016 tentang petunjuk pelaksanaan lelang menyatakan bahwa risalah lelang adalah berita acara pelaksanaan lelang yang dibuat oleh pejabat lelang yang merupakan akta outentik dan mempunyai kekuatan pembuktian yang sempurna.

Fungsi lelang ada 2, yaitu fungsi privat dan fungsi public. Fungsi privat dalam lelang yaitu sebagai sarana transaksi jual beli barang yang memperlancar arus lalu lintas perdagangan barang, karena lelang merupakan suatu instrumen pasar yang mengakomodir keinginan pasar dalam melakukan jual beli.

Sedangkan fungsi publik dalam lelang adalah :

1. Pada saat digunakan oleh aparatur Negara untuk menjalankan tugas umum pemerintahan dibidang penegakan hukum dan pelaksanaan undang-undang 
2. Mendukung tertib administrasi dan efisiensi pengelolaan dan pengurusan aset yang dimiliki atau dikuasai Negara

3. Mengumpulkan atau mengamankan penerimaan Negara baik Penerimaan Negara Bukan Pajak (PNBP) dalam bentuk Bea Lelang dan Biaya Administrasi, maupun Penerimaan Perpajakan berupa PPH pasal 25 dan Bea Perolehan Ha k atas Tanah dan bangunan (BPHTB).

4. Mendukung terwujudnya good Government mengingat lelang mempunyai asas-asas yaitu transparansi, kepastian hukum, kompetisi, efisiensi dan akuntabilitas

Berdasarkan studi teoritis, lelang memiliki prinsip dan asas-asas yang mendasarinya dan harus dipenuhi dalam penjualan melalui lelang yang berlaku di Indonesia antara lain :

1. Asas Transparansi

2. Asas Kepastian Hukum

3. Asas Kompetisi

4. Asas Efisiensi

5. Asas Akuntabilitas

Dalam Peraturan Menteri Keuangan Nomor 176/PMK.06/2010 tentang Balai Lelang menyatakan bahwa yang dimaksud dengan Balai Lelang adalah Badan Hukum Indonesia berbentuk Perseroan Terbatas (PT) yang khusus didirikan untuk melakukan kegiatan usaha dibidang lelang.Dalam proses lelang eksekusi penjual dimungkinkan untuk bekerjasama dengan balai lelang, yaitu sebagai penyelenggara pralelang. Jasa pralelang yang dilakukan balai lelang meliputi:

1. Meneliti dan melakukan analisis yuridis terhadap dokumen persyaratan lelang dan dokumen barang yang akan dilelang;

2. Menerima, mengumpulkan, memilah, memberi label, dan menyimpan barang yang akan dilelang;

3. Menguji, meningkatkan kualitas, menilai harga, dan mengatur asuransi barang yang akan dilelang;

4. Memasarkan barang dengan cara-cara efektif, terarah serta menarik baik dengan pengumuman, brosur, katalog maupun cara pemasaran lainnya.

\section{Gambar 1 Alur Pikir Penelitian}

Properti riil obyek lelang Eksekusi HT<smiles>C1CCCC1</smiles>

Ekspektasi nilai dan pemasaran

Faktor-faktor yang berpengaruh:

1. Lokasi

2. Aksesibilitas

3. Penyelenggara Pra lelang

4. Penawaran lelang internet

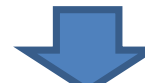

Keberhasilan lelang eksekusi HT

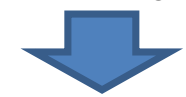

Data : KPKNL Palu

2015-Sept 2016

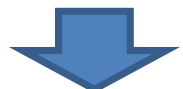


Analisis regresi berganda binari

model logit

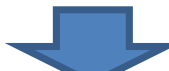 \\ Hasil Analisis \\ METODE PENELITIAN}

\section{Data dan Sumber Data}

Data yang digunakan dalam penelitian ini adalah data primer dan data sekunder, sumber data diperoleh dari :

1. Laporan KPKNL Palu kepada Kanwil DJKN Sulawesi Utara Tengah Gorontalo dan Maluku Utara berupa data lelang eksekusi hak tanggungan di KPKNL Palu untuk tahun 2015 sampai dengan September 2016

2. Salinan Risalah Lelang dan Minuta risalah lelang atas pelaksanaan lelang eksekusi Hak Tanggungan pada KPKNL Palu Periode tahun 2015 sampai dengan Bulan September 2016

3. Selain itu juga diadakan penelitian perpustakaan mengenai teori, pengertian yang bersumber dari buku-buku atau literatur, jurnal-jurnal, serta publikasi lainnya yang terkait dengan penelitian dan penulisan ini.

\section{Ruang Lingkup Penelitian}

Analisis dilakukan dengan menggunakan data sekunder yang diperoleh dari laporan berdasarkan jenis lelang dari KPKNL Palu periode tahun 2015 sampai dengan September 2016 dan data primer berupa salinan risalah lelang dan minuta risalah lelang eksekusi Hak Tanggungan pada KPKNL Palu. Dalam penelitian ini dibatasi cakupan analisis terhadap pelaksanaan lelang Hak Tanggungan properti riil yang terletak di Kota Palu.

\section{Teknik Pengambilan Sampel}

Metode pengambilan sampel dengan metode sampling acak sederhana (simple random sampling) secara proporsional. Populasi dibagi ke dalam kelompok berdasarkan tahun pelaksanaan lelang dan laku atau tidak laku terjual lelang. Kemudian sampel dipilah lagi berdasarkan pemohon lelang untuk memilah pelaksanaan lelang obyek hak tanggungan yang berlokasi di Kota Palu. Setelah itu diambil sampel secara acak dari masing-masing kelompok secara proporsional.

\section{Definisi Operasional dan Pengukuran Variabel}

Variabel-variabel yang diamati dalam penelitian ini meliputi : hasil lelang properti riil, lokasi, aksesibilitas, penyelenggara pra lelang, dan cara penawaran lelang melalui internet.

1. Hasil lelang dalam penelitian ini adalah berhasil atau tidaknya suatu properti riil terjual melalui lelang. Berhasil berarti bahwa properti riil tersebut laku terjual dan sebaliknya tidak berhasil jika properti riil tersebut tidak laku terjual dalam suatu pelaksanaan lelang. Untuk lelang yang berhasil atau laku terjual mempunyai nilai 1, sedangkan untuk lelang yang tidak berhasil mempunyai nilai 0 .

2. Lokasi properti riil dalam penelitian ini adalah seberapa jauh jarak lokasi properti riil dengan CBD, yang diukur dalam satuan kilo meter $(\mathrm{km})$

3. Aksesibilitas dalam penelitian ini adalah akses jalan atau lebar jalan menuju lokasi obyek lelang properti riil. Lebar jalan sangat mempengaruhi mobilitas dari dan menuju lokasi properti riil, sehingga orang akan cenderung memilih properti riil yang mempunyai akses jalan yang lebar. Satuan ukuran yang digunakan dalam penelitian ini adalah meter (m).

4. Penyelenggara pra lelang dalam penelitian ini adalah apakah pelaksanaan lelang obyek properti riil menggunakan perantara jasa balai lelang dalam pengurusan pra lelang atau tanpa menggunakan jasa balai lelang. Untuk pelaksanaan lelang yang menggunakan jasa balai belang mempunyai nilai 1, sedangkan untuk lelang yang tidak menggunakan jasa balai lelang mempunyai nilai 0 .

5. Cara Penawaran Lelang melalui internet dalam penelitian ini adalah Pelaksanaan Lelang obyek properti riil didasarkan atas cara penawarannya apakah dilakukan melalui media 
internet (e-auction) maupun secara langsung dihadapan Pejabat Lelang. Untuk lelang yang dilakukan melalui internet mempunyai nilai 1, sedangkan untuk lelang yang dilakukan langsung dihadapan Pejabat Lelang mempunyai nilai 0.

\section{Metode Analisis}

Model yang digunakan dalam penelitian ini adalah logit, di mana nilai prediksi Y terletak antara 0 sampai dengan 1 . Model logit adalah suatu cara untuk mengkuantitatifkan hubungan antara probabilitas dua pilihan dengan beberapa karakteristik yang dipilih. Suatu probabilitas merupakan angka satu (lelang yang laku terjual) serta nol (lelang yang tidak laku terjual). Estimasi logit untuk data kelompok adalah dengan estimasi metode OLS (Ordinary Least Square), sedangkan jika datanya individual digunakan estimasi metode maximum likelihood (Widarjono, 2007: 220-222). Dalam penelitian ini datanya individual maka digunakan estimasi model logit dengan metode maximum likelihood.

Bentuk umum model logit dapat dirumuskan sebagai berikut (Kuncoro, 2001: 210).

$$
\begin{aligned}
& \text { Pi } \\
& \mathrm{Li}=\log \text {------ }=b_{0}+b_{1} X_{1}+b_{2} X_{2+\ldots \ldots . .+} b_{i} X_{k} \\
& \text { 1- Pi } \\
& \text { di mana: } \quad \mathrm{Li} \quad=\text { Variabel dependen } \\
& \mathrm{Pi}_{\mathrm{i}} \\
& { }_{1-\mathrm{P}_{\mathrm{i}}}=\text { odds ratio } \\
& \mathrm{X}=\text { Variabel independen, yang digunakan sebagai penjelas } \mathrm{Li} \\
& \mathrm{b}_{0} \quad=\text { Intercept } \text {, titik potong garis regresi dengan sumbu vertikal } \\
& \mathrm{b}_{1} . . \mathrm{b}_{3}=\text { Slope, kemiringan garis regresi yang menunjukkan arah } \\
& \text { gerak dari Li. }
\end{aligned}
$$

Ciri utama model logit adalah (Gujarati, 2003: 596) :

1. karena nilai $\mathrm{P}$ bergerak dari 0 sampai 1 , nilai logit adalah tidak terbatas;

2. walaupun nilai L linier dalam X, namun probabilitas $P$ tidak. Inilah perbedaan utama antara model logit dan linear probability model (LPM), karena probabilitas pada LPM meningkat secara linier bersama X;

3. interpretasi formal dari model logit adalah sebagai berikut: koefisien $b_{j}$ mengukur seberapa jauh perubahan L akibat perubahan X sebesar satu unit. Intersep adalah nilai odds ratio ketika variabel independen sama dengan nol;

4. jika LPM berasumsi bahwa $\mathrm{P}_{\mathrm{i}}$ adalah linier terhadap $\mathrm{X}$, maka model logit berasumsi bahwa rasio dari log odds adalah linier terhadap $\mathrm{X}$

Model regresi tentang faktor-faktor yang mempengaruhi keberhasilan lelang diantaranya dikembangkan oleh Ong et. al. (2005: 179), Ong, Lusht dan Mak (2004:6) dan Widodo (2008). Model dari Ong et. al. (2005) adalah :

OUT $=f($ LRP, SOM, DATE, LOC, AH, TYPE, VP, DISTR, TEN, TURN)

Dalam hal ini variabel dependen OUT adalah keberhasilan lelang, sedangkan variabel independen terdiri dari level of reserve price (LRP), kondisi pasar (SOM), tanggal pelaksanaan lelang (DATE), lokasi (LOC), penyelenggara pralelang (AH), tipe real estat (TYPE), posisi kekosongan (VP), penjualan dalam kondisi tertekan (DISTR), status kepemilikan (TEN) dan jumlah penawar (TURN). Variabel OUT, SOM, DATE, LOC, AH, TYPE, VP, DISTR, dan TEN adalah variabel boneka (dummy variable).

Berdasarkan model yang dikembangkan oleh Ong, Lusht dan Mak (2004: 6) tentang faktor yang mempengaruhi keberhasilan lelang, yaitu :

\section{OUT $=f($ LRP,SOM,DATE,LOC,AH,TYPE,VP,DISTR,TEN,TURN)}

di mana variabel dependen OUT adalah hasil lelang, sedangkan variabel independen terdiri dari Level of Reserve Price (LRP), kondisi pasar (SOM), tanggal pelaksanaan lelang (DATE), lokasi (LOC), pelaksana lelang (AH), tipe real estate (TYPE), posisi kekosongan (VAC), penjualan dalam kondisi tertekan (DISTR), tenure (TEN) dan jumlah penawar (TURN).

Model yang digunakan dalam penelitian Widodo (2008) adalah 
OUT $=f($ LOC, ACC, TYPE, AH).

Dimana : Dalam hal ini variabel dependen OUT adalah hasil lelang, sedangkan variabel independen terdiri lokasi (LOC), aksesibilitas (ACC), tipe real estat (TYPE), dan penyelenggara pralelang (AH). Variabel OUT, LOC, TYPE, dan AH adalah variabel boneka. Variabel ACC adalah variabel kuantitatif berupa lebar jalan menuju lokasi properti yang diukur dalam meter.

Berangkat dari model-model di atas maka model regresi yang dikembangkan dalam penelitian ini adalah sebagai berikut

$$
\text { OUT }=b_{0}+b_{1} \mathbf{L O C}+b_{2} \mathbf{A C C}+b_{3} \mathbf{A H}+b_{4} \mathbf{H t Q}+e_{i}
$$

Dalam hal ini :

OUT = adalah keberhasilan lelang $(1=$ laku terjual, $0=$ tidak laku terjual $)$;

b0 = intercept, yang menunjukkan tingkat konstanta OUT;

b1 ...b5 = slope, yang menunjukkan arah gerak dari OUT;

$\mathrm{e}_{\mathrm{i}} \quad=$ variabel gangguan

LOC = adalah lokasi berupa jarak properti riil dari CBD

ACC = adalah aksesibilitas berupa lebar jalan menuju lokasi properti

$\mathrm{AH}=$ adalah penyelenggara pralelang $(1=$ melalui Balai Lelang, $0=$ tidak melalui Balai Lelang)

HtQ = adalah cara penawaran lelang $(1=$ melalui internet, $0=$ tidak melalui internet $)$

Proses analisis data dilakukan dengan program Eviews 8.0 dengan menggunakan model logit. Selanjutnya untuk melihat apakah hasil estimasi dari model sudah baik atau belum, maka diperlukan pengujian :

1. Uji Kriteria Ekonomika/Apriori

2. Uji Kriteria Statistik :

a. Pengujian koefisien regresi secara individu

Uji ini dilakukan dilakukan untuk mengestimasi pengaruh masing-masing variabel independen terhadap variabel dependen. Apabila probabilitas (prob) $>0,05$, maka hipotesis nol atau $\mathrm{H}_{0}$ (koefisien regresi tidak berpengaruh) tidak dapat ditolak. Sebaliknya apabila probabilitas (prob) $<0,05$, maka hipotesis alternatif atau $\mathrm{H}_{\mathrm{a}}$ (koefisien regresi berpengaruh) diterima.

b. Pengujian koefisien regresi secara bersama-sama

Uji ini dilakukan untuk mengetahui pengaruh variabel independen secara bersamasama terhadap variabel dependen. Apabila probabilitas (LR stat) dari model > 0,05 , maka hipotesis nol atau $\mathrm{H}_{0}$ (koefisien regresi secara bersama-sama tidak berpengaruh) tidak dapat ditolak. Sebaliknya apabila probabilitas (LR stat) dari model $<0,05$ maka hipotesis alternatif atau Ha (koefisien regresi secara bersamasama berpengaruh) tidak dapat ditolak.

c. Menguji kelayakan model regresi

Uji ini dilakukan untuk mengetahui kemampuan variabel independen menerangkan variabel dependen. Dalam model logit digunakan McFadden R-Squared.

3. Uji Ekonometrika

\section{Hasil Regresi}

\section{HASIL PENELITIAN DAN PEMBAHASAN}

Untuk menganalisis faktor yang mempengaruhi hasil lelang, digunakan analisis regresi berganda model logit. Adapun model yang digunakan dalam penelitian ini adalah sebagai berikut

$$
\text { OUT }=b_{0}+b_{1} \mathbf{L O C}+b_{2} \mathbf{A C C}+b_{3} \mathbf{A H}+b_{4} \mathbf{H t Q}+e_{i}
$$

Dimana:

OUT = adalah keberhasilan lelang $(1=$ laku terjual, $0=$ tidak laku terjual $)$;

b0 = intercept, yang menunjukkan tingkat konstanta OUT;

b1 ...b5 = slope, yang menunjukkan arah gerak dari OUT; 
$\mathrm{e}_{\mathrm{i}} \quad=$ variabel gangguan

LOC = adalah lokasi berupa jarak properti riil dari CBD

ACC = adalah aksesibilitas berupa lebar jalan menuju lokasi properti

$\mathrm{AH}=$ adalah penyelenggara pralelang $(1=$ melalui Balai Lelang, $0=$ tidak melalui Balai Lelang)

HtQ = adalah cara penawaran lelang $(1=$ melalui internet, $0=$ tidak melalui internet $)$

Berdasarkan pada persamaan di atas diperoleh hasil regresi dengan menggunakan program Eviews 8.0 sebagaimana tersaji pada Tabel berikut. Sebelum melakukan interpretasi dan analisis lebih lanjut, untuk mengetahui baik tidaknya model regresi berganda maka perlu dilakukan pengujian. Dalam hal ini pengujian dilakukan dengan menggunakan 3 uji kriteria, yaitu uji kriteria ekonomika, uji kriteria statistika, dan uji kriteria ekonometrika.

Tabel 1

Hasil Regresi

\begin{tabular}{lrlrr}
\hline \hline \multicolumn{1}{c}{ Variable } & Coefficient & \multicolumn{1}{c}{ Std. Error } & z-Statistic & Prob. \\
\hline \hline \multicolumn{1}{c}{ LOC } & 0.475202 & 0.081726 & 5.814580 & 0.0000 \\
HTQ & 2.007687 & 0.664245 & 3.022510 & 0.0025 \\
AH & 1.704879 & 0.614460 & 2.774597 & 0.0055 \\
ACC & 0.689941 & 0.224877 & 3.068084 & 0.0022 \\
C & -16.67303 & 3.029652 & -5.503285 & 0.0000 \\
\hline \hline McFadden R-squared & 0.694380 & Mean dependent var & 0.345000 \\
S.D. dependent var & 0.476561 & S.E. of regression & 0.250835 \\
Akaike info criterion & 0.443820 & Sum squared resid & 12.26910 \\
Schwarz criterion & 0.526278 & Log likelihood & -39.38201 \\
Hannan-Quinn criter. & 0.477190 & Deviance & 78.76402 \\
Restr. deviance & 257.7186 & Restr. log likelihood & -128.8593 \\
LR statistic & 178.9545 & Avg. log likelihood & -0.196910 \\
Prob(LR statistic) & 0.000000 & & 200 \\
\hline \hline Obs with Dep=0 & \multicolumn{2}{|c}{131} & Total obs & \\
Obs with Dep=1 & 69 & & \\
\hline
\end{tabular}

Sumber : KPKNL Palu, Risalah Lelang, 2015-September 2016 (diolah)

\section{Hasil Uji Kriteria Ekonomika/Apriori}

Tabel 2

Uji Kriteria Ekonomika Hasil Regresi

\begin{tabular}{|l|l|c|}
\hline \multicolumn{1}{|c|}{ Variabel } & Koefisien & Keterangan \\
\hline Lokasi (LOC) & 0.475202 & Sesuai dengan teori \\
\hline Aksesibilitas (ACC) & 0.689941 & Sesuai dengan teori \\
\hline Penyelenggara pralelang (AH) & 1.704879 & Sesuai dengan teori \\
\hline Cara penawaran (HtQ) & 2.007687 & Sesuai dengan teori \\
\hline
\end{tabular}

Sumber : KPKNL Palu, Risalah Lelang, 2015-September 2016 (diolah)

Hasil regresi menunjukkan arah atau tanda koefisien variabel lokasi properti riil (LOC) adalah positif sehingga mempunyai hubungan yang positif terhadap hasil lelang. Hal ini sesuai dengan teori dan penelitian yang dilakukan oleh Ong dkk. (2005: 9);

Hasil regresi menunjukkan arah atau tanda koefisien variabel aksesibilitas properti riil (ACC) adalah positif sehingga mempunyai hubungan yang positif terhadap hasil lelang. Hal 
ini sesuai dengan teori Fanning dkk. (1994: 59) yang menyatakan bahwa aksesibilitas properti riil yang semakin baik lebih diminati dan oleh karenanya akan meningkatkan potensial nilai pasar sekaligus probabilitas terjualnya properti riil dimaksud.

Hasil regresi menunjukkan arah atau tanda koefisien variabel penyelenggara pra lelang (AH) adalah positif sehingga mempunyai hubungan yang positif terhadap hasil lelang. Hal ini sudah sesuai dengan teori dan penelitian yang dilakukan oleh Ong dkk. (2005: 9) bahwa penyelenggara lelang properti riil berpengaruh positif terhadap harga dan probabilitas terjualnya riil properti tersebut dalam lelang.

Hasil regresi menunjukkan arah atau tanda koefisien variabel cara penawaran lelang (HtQ) adalah positif sehingga mempunyai hubungan yang positif terhadap hasil lelang. Hal ini berarti penawaran melalui internet akan meningkatkan kemungkinan sebuah asset untuk laku terjual dibandingkan penawaran tidak melalui internet. Hal ini sudah sesuai dengan teori dan penelitian yang dilakukan oleh Wan dan Teo (2001) yang meneliti tentang faktor yang mempengaruhi hasil serta harga suatu property melalui lelang internet.

\section{Uji Kriteria Statistik}

Tabel 3

Hasil Pengujian Secara Individu

\begin{tabular}{|l|l|l|l|l|}
\hline Variable & Coefficient & Z-Statistic & Probability & Kesimpulan \\
\hline LOC & 0.475202 & 5.814580 & 0.0000 & Signifikan \\
\hline HTQ & 2.007687 & 3.022510 & 0.0025 & Signifikan \\
\hline AH & 1.704879 & 2.774597 & 0.0055 & Signifikan \\
\hline ACC & 0.689941 & 0.224877 & 0.0022 & Signifikan \\
\hline Constant & -16.67303 & -5.503285 & 0.0000 & \\
\hline McFadden R-squared & 0.694380 & & \\
\hline LR statistic & 178.9545 & & \\
\hline \multicolumn{2}{|l|}{ Prob(LR statistic) } & 0.000000 & & \\
\hline
\end{tabular}

Sumber : KPKNL Palu, Risalah Lelang, 2015-September 2016 (diolah)

Pengujian pengaruh secara bersama-sama dilakukan untuk mengetahui pengaruh variabel independen secara bersama-sama terhadap variabel dependen. Apabila probabilitas (LR stat) dari model $>0,05$, maka hipotesis nol atau $\mathrm{H}_{0}$ (koefisien regresi secara bersama-sama tidak berpengaruh) tidak dapat ditolak. Sebaliknya apabila probabilitas (LR stat) dari model $<0,05$, maka hipotesis alternatif atau $\mathrm{Ha}_{\mathrm{a}}$ (koefisien regresi secara bersama-sama berpengaruh) tidak dapat ditolak.

Tabel 4

Hasil Pengujian Secara Bersama-sama

\begin{tabular}{|c|c|c|c|}
\hline Model & Df & LR Statistic & Probabilitas \\
\hline Logit & 3 & 178.9545 & 0,000 \\
\hline
\end{tabular}

Sumber : KPKNL Palu, Risalah Lelang, 2015-September 2016 (diolah)

Berdasarkan perhitungan dalam tabel 4.6 menunjukkan bahwa nilai probabilitas dari model adalah sebesar 0,000 yang berarti lebih kecil dari 0,05. Hal ini berarti bahwa keempat variabel independen, yaitu lokasi (LOC), aksesibilitas (ACC), penyelenggara pralelang (AH) dan cara penawaran (HtQ) berpengaruh signifikan terhadap variabel dependen yaitu hasil lelang (OUT) eksekusi tanggungan pada KPKNL Palu.

Pengujian kelayakan model (goodness of fit) dilakukan untuk mengetahui kemampuan variabel independen menerangkan variabel dependen. Mcfadden $R$-Squared digunakan dalam pengujian ini mengingat model yang digunakan adalah model logit. Berdasarkan hasil regresi model logit (tabel 4.3) diketahui bahwa nilai Mcfadden R-Squared adalah sebesar 0.694380. Mcfadden R-Squared sebesar 0.694380 ini mempunyai arti bahwa kemampuan variabel independen menerangkan variabel dependen adalah sebesar 69,44 persen. Perhitungan Mcfadden R-Squared menujukkan bahwa variabel dependen pada model ini sebagian besar dapat diterangkan oleh variabel independen (lebih dari 50 persen), dan sisanya diterangkan 
oleh faktor-faktor lain. Selain dengan MacFadden $R$-squared, kemampuan model atau goodness of fit dapat dilihat dari daya prediksi model tersebut yaitu besarnya kemampuan model memprediksi dengan benar dari jumlah yang diklasifikasi atau besarnya Count $R$ Squared (Gujarati, 2003: 606). Berdasarkan expectation prediction table (lampiran 3) menunjukkan bahwa model dapat memprediksi 186 obyek lelang dari 200 obyek lelang dengan benar atau mencapai 93 persen. Hal ini berarti bahwa model penelitian ini layak digunakan untuk memprediksi.

\section{Hasil Uji Ekonometrika}

Uji kriteria ekonometri atau disebut juga uji asumsi klasik adalah uji yang dilakukan untuk menguji asumsi regresi klasik yang dikemukakan oleh Gujarati (2003: 59-69). Untuk model logit tidak dilakukan uji normalitas dan uji heteroskedastisitas karena:

1. Sebagai model yang bersifat binari dalam variabel dependennya yang hanya mempunyai dua nilai, maka model logit residualnya jelas tidak berdistribusi normal (Widarjono, 2005: 205). Hal ini bisa dijelaskan sebagai berikut:

$\mathrm{Yi}=\mathrm{b}_{0}+\mathrm{b}_{1} \mathrm{X}_{\mathrm{i}}+\mathrm{e}_{\mathrm{i}}$ (3.3) Maka residualnya:

$\mathrm{e}_{\mathrm{i}}=\mathrm{Y}_{\mathrm{i}}-\mathrm{b}_{0}-\mathrm{b}_{1} \mathrm{X}_{\mathrm{i}}$ (3.4) Jika $\mathrm{Y}_{\mathrm{i}}=1$

maka $e_{i}=1-b_{0}-b_{1} X_{i}$

Jika $Y_{i}=0$ maka ei $=0-b_{i}-b_{1} X_{i}$

Jadi bisa dilihat bahwa residualnya tidak berdistribusi normal tetapi mengikuti distribusi binomial;

2. Residual dari model logit juga mengandung unsur heteroskedastisitas meskipun kita tetap mempertahankan $\mathrm{E}\left(\mathrm{e}_{\mathrm{i}}\right)=0$ (Widarjono, 2005: 206). Hal ini terjadi karena ei mengikuti distribusi binomial, di mana variabel dependen bersifat kualitatif (dummy variabel) yang mengambil nilai 0 dan 1 . Dalam penelitian yang mempunyai variabel dependen bersifat kualitatif, asumsi homoskedastik dari variabel gangguan tidak dapat dipenuhi karena varian gangguan tergantung pada harapan bersyarat dari $\mathrm{Y}$, yang tergantung pada nilai yang diambil oleh $\mathrm{X}$ dan pada akhirnya residual $\left(\mathrm{e}_{\mathrm{i}}\right)$ tergantung pada X, karena itu tidak homoskedastik (Gujarati, 2003: 388-393). Artinya, varian dari variabel gangguan bukan suatu konstanta melainkan bervariasi sesuai dengan perubahan variabel dependen $\mathrm{Y}_{\mathrm{i}}$, atau dengan variabel independen $\mathrm{X}_{\mathrm{i}}$.

Tabel 5

Korelasi Antar Variabel Independen

\begin{tabular}{|c|c|c|c|c|}
\hline & LOC & HTQ & AH & ACC \\
\hline LOC & 1.000000 & 0.139503 & 0.259874 & 0.376280 \\
\hline HTQ & 0.139503 & 1.000000 & 0.081328 & 0.146880 \\
\hline AH & 0.259874 & 0.081328 & 1.000000 & 0.246321 \\
\hline ACC & 0.376280 & 0.146880 & 0.246321 & 1.000000 \\
\hline
\end{tabular}

Sumber : KPKNL Palu, Risalah Lelang, 2015-September 2016 (diolah)

\section{Pembahasan}

Hasil lelang yang dilihat atau diukur dengan laku terjual dan tidak laku terjual properti riil dalam pelelangan dipengaruhi secara signifikan oleh faktor lokasi, aksesibilitas, tipe properti dan penyelenggara pra lelang. Berdasarkan hasil analisis regresi model logit, estimasi model persamaan dalam penelitian ini dapat dirumuskan sebagai berikut.

$$
\mathrm{Li}=\ln \frac{P_{i}}{1-P_{i}}=-16,6730+0,4752 \mathrm{LOC}+0,6899 \mathrm{ACC}+1,7049 \mathrm{AH}+2,0077 \mathrm{HtQ}
$$


di mana :

$$
\begin{aligned}
& P_{i} \\
& 1-P_{i} \quad=\text { Odds ratio } \\
& \text { LOC = adalah lokasi berupa jarak properti riil dari CBD } \\
& \text { ACC = adalah aksesibilitas berupa lebar jalan menuju lokasi properti } \\
& \mathrm{AH}=\text { adalah penyelenggara pralelang }(1=\text { melalui Balai Lelang, } 0=\text { tidak melalui } \\
& \text { Balai Lelang) } \\
& \text { HtQ = adalah cara penawaran lelang }(1=\text { melalui internet, } 0=\text { tidak melalui }
\end{aligned}
$$

Hasil Interpretasi regresi model penelitian ini secara ringkas tersaji dalam tabel 4.8 sebagai berikut.

Tabel 6

Hasil Regresi dan Interpretasi

\begin{tabular}{|l|c|c|}
\hline \multicolumn{1}{|c|}{ Variabel } & Koefisien $(b)$ & Odds ratio $\left(e^{b}\right)$ \\
\hline Konstanta & -16.67303 & 0.00000 \\
Lokasi (LOC) & 0.475202 & 1.60826 \\
Aksesibilitas (ACC) & 0.689941 & 1.99346 \\
Penyelenggara Pra Lelang (AH) & 1.704879 & 5.49975 \\
Cara Penawaran (HtQ) & 2.007687 & 7.44452 \\
\hline
\end{tabular}

Sumber : KPKNL Palu, Risalah Lelang, 2015-September 2016 (diolah)

Konstanta bernilai negatif dan signifikan pada tingkat keyakinan 95\%. Hal ini berarti bahwa jika semua variabel bebas mempunyai nilai nol maka log odds ratio mempunyai nilai negatif sebesar -16.6730. Berdasarkan perhitungan terhadap log odds ratio dari nilai konstanta tersebut $\left(e^{-16,6730}=0,00000\right)$, diketahui bahwa probabilitas terjualnya properti riil melalui lelang adalah sebesar 0,00000 . Dengan kata lain, apabila semua variabel bebas bernilai nol maka probabilitas terjualnya riil properti tersebut melalui lelang adalah nol atau tidak akan terjual.

Lokasi riil properti di kota secara statistik berpengaruh terhadap hasil lelang pada tingkat keyakinan $95 \%$. Artinya, ada perbedaan pengaruh properti riil yang berlokasi di wilayah dekat dengan CBD atau berada dipusat kota dengan properti riil yang berlokasi jauh dari CBD atau berada di luar kota terhadap probabilitas hasil lelang. Hasil regresi menunjukkan arah atau tanda koefisien variabel lokasi properti riil adalah positif, hal ini sesuai dengan teori dan penelitian yang dilakukan oleh Ong dkk. (2005: 9); Ooi dkk. (2004: 12); Deboer, Conrad, McNamara serta Asabere dan Huffman dalam Ong dkk. (2005: 5) bahwa lokasi properti riil berpengaruh terhadap harga dan probabilitas terjualnya properti riil tersebut dalam lelang.

Koefisien regresi variabel lokasi sebesar 0,475202 menunjukkan bahwa properti riil yang berlokasi dekat dengan CBD akan meningkatkan log odds ratio sebesar 0,475202 dengan asumsi variabel independen yang lain tetap. Berdasarkan perhitungan log odds ratio dari koefisien variabel lokasi $\left(e^{0,475202}=1,60826\right)$, dapat diketahui bahwa hasil lelang berupa terjualnya obyek lelang properti riil yang berlokasi dekat dengan CBD akan meningkat sebesar 1,60826 kali, dengan asumsi variabel independen yang lain tetap.

Aksesibilitas berupa lebar jalan menuju lokasi properti riil obyek lelang secara 
statistik berpengaruh positif terhadap hasil lelang pada tingkat keyakinan 95\%. Hal ini sesuai dengan teori Fanning dkk. (1994: 59) yang menyatakan bahwa aksesibilitas properti riil yang semakin baik lebih diminati dan oleh karenanya akan meningkatkan potensial nilai pasar sekaligus probabilitas terjualnya properti riil dimaksud. Oleh karena pada dasarnya aksesibilitas merupakan aspek spesifik dari lokasi.

Koefisien regresi variabel aksesibilitas berupa lebar jalan menuju lokasi properti riil sebesar 0,689941 menunjukkan bahwa setiap penambahan lebar jalan menuju lokasi properti riil selebar 1 meter akan menambah nilai log odds ratio sebesar 0,689941 dengan asumsi variabel independen yang lain tetap. Dengan menghitung odds ratio koefisien variabel aksesibilitas berupa lebar jalan $\left(e^{0,689941}=1,99346\right)$. Artinya penambahan lebar jalan 1 meter akan meningkatkan hasil lelang berupa terjualnya properti riil sebesar 1,99346 kali, dengan asumsi variabel independen yang lain tetap.

Proses pra lelang yang diselenggarakan oleh balai lelang secara statistik berpengaruh positif terhadap hasil lelang pada tingkat keyakinan 95\%. Artinya ada perbedaan pengaruh antara lelang riil properti yang proses pra lelangnya diselenggarakan oleh balai lelang dengan lelang yang proses pra lelangnya tidak diselenggarakan oleh balai lelang. Hal ini sudah sesuai dengan teori dan penelitian yang dilakukan oleh Ong dkk. (2005: 9) bahwa penyelenggara lelang properti riil berpengaruh positif terhadap harga dan probabilitas terjualnya riil properti tersebut dalam lelang.

Koefisien regresi variabel boneka penyelenggara pra lelang sebesar 1,704879 menunjukkan bahwa lelang riil properti yang proses pra lelangnya diselenggarakan oleh balai lelang akan menaikkan $\log$ odds ratio sebesar 1,704879 dengan asumsi variabel independen yang lain tetap. Interpretasi terhadap odds ratio dari koefisien variabel penyelenggara pra lelang $\left(e^{1,704879}=5,49975\right)$. Sehingga dapat diketahui bahwa kecenderungan hasil lelang berupa terjualnya obyek lelang properti riil melalui lelang yang proses pra lelangnya diselenggarakan oleh balai lelang adalah sebesar 5,49975 kali, dengan asumsi variabel independen yang lain tetap.

Cara penawaran lelang secara statistik berpengaruh positif terhadap keberhasilan lelang pada tingkat keyakinan $95 \%$. Artinya terdapat perbedaan antara penawaran lelang melalui internet terhadap kemungkinan sebuah asset untuk laku terjual dibandingkan penawaran tidak melalui internet.

Koefisien regresi variabel boneka cara penawaran lelang sebesar 2,007687 menunjukkan bahwa lelang riil properti yang cara penawarannya melalui internet akan menaikkan log odds ratio sebesar 2,007687 dengan asumsi variabel independen yang lain tetap. Interpretasi terhadap odds ratio dari koefisien variabel penyelenggara pra lelang $(e$ 2,007687

$=7,44452$ ). Sehingga dapat diketahui bahwa kecenderungan hasil lelang berupa terjualnya obyek lelang properti riil yang cara penawaran lelangnya melalui internet adalah sebesar 7,44452 kali, dengan asumsi variabel independen yang lain tetap.

Berdasarkan hasil penelitian tersebut diatas menunjukan bahwa variabel penelitian yang digunakan berupa lokasi properti riil yang berlokasi dekat dengan CBD, aksesibilitas berupa lebar jalan menuju lokasi properti riil, pelaksanaan lelang yang proses pra lelangnya diselenggarakan oleh balai lelang dan cara penawaran lelangnya melalui internet mempengaruhi kecenderungan hasil lelang berupa terjualnya obyek lelang yang berlokasi di kota Palu, dengan asumsi kondisi faktor-faktor yang mempengaruhi daya beli masyarakat diantaranya pendapatan perkapita, tingkat pendidikan, kesenjangan sosial dan ekonomi, situasi politik dan tingkat inflasi dalam kondisi baik.

\section{KESIMPULAN}

1. Variabel lokasi (LOC) properti riil obyek lelang eksekusi hak tanggungan secara statistik berpengaruh positif terhadap hasil lelang eksekusi hak tanggungan di KPKNL Palu. Hal ini menunjukkan properti riil yang berlokasi dekat dengan CBD atau berada dalam wilayah perkotaan probabilitas keberhasilan lelang (laku terjual lelang) lebih besar dibandingkan dengan properti riil yang berlokasi di jauh dari CBD atau berada di luar 
kota.

2. Variabel aksesibilitas (ACC) berupa lebar jalan menuju lokasi properti riil obyek lelang secara statistik berpengaruh positif terhadap hasil lelang eksekusi hak tanggungan di KPKNL Palu. Hal ini berarti, semakin lebar jalan menuju properti riil semakin besar probabilitas keberhasilan lelang (laku terjual lelang).

3. Variabel penyelenggara pralelang $(\mathrm{AH})$ secara statistik berpengaruh positif terhadap hasil lelang eksekusi hak tanggungan di KPKNL Palu. Hal ini menunjukkan proses pralelang diselenggarakan oleh balai lelang akan meningkatkan probabilitas keberhasilan lelang (laku terjual lelang) dibandingkan dengan yang proses pralelangnya tidak diselenggarakan oleh balai lelang.

4. Variabel cara penawaran lelang (HtQ) secara statistik berpengaruh positif terhadap hasil lelang eksekusi hak tanggungan di KPKNL Palu. Hal ini menunjukkan proses lelang yang cara penawarannya melalui internet akan meningkatkan probabilitas keberhasilan lelang (laku terjual lelang) dibandingkan dengan yang proses lelang yang cara penawarannya dilakukan secara konvensional.

\section{SARAN}

1. Variabel independen berupa lokasi (LOC) yang dekat dengan CBD, aksesibilitas (ACC) berupa lebar jalan menuju obyek properti riil, penyelenggara pralelang $(\mathrm{AH})$ oleh balai lelang dan cara penawaran lelang (HtQ) melalui internet berpengaruh positif terhadap hasil lelang (OUT) di KPKNL Palu, sehingga untuk setiap pelaksanaan lelang eksekusi hak tanggungan pihak kreditor dan KPKNL perlu mempertimbangkan faktor lokasi yang baik, aksesibilitas yang lebih baik, melibatkan balai lelang dalam proses penyelenggaraan pralelang dan memilih cara penawaran lelang melalui internet. Hal ini perlu dilakukan agar probabilitas keberhasilan lelang (laku terjual) semakin besar. Dengan tingkat keberhasilan lelang yang semakin baik maka dapat mengurangi masalah yang dihadapi kreditor/perbankan (menurunkan tingkat kredit bermasalah /non performing loan), disisi lain juga akan dapat meningkatkan penerimaan negara berupa bea lelang dan Pajak Penghasilan serta penerimaan daerah dari sektor pajak daerah berupa Bea Perolehan Hak Atas Tanah dan Bangunan (BPHTB).

2. Pihak kreditor sebagai pemohon lelang sebaiknya mempertimbangkan menggunakan jasa balai lelang pada proses pralelang, hal ini sesuai hasil penelitian ini dengan melibatkan balai lelang pada proses pralelang berpengaruh positif terhadap hasil lelang. Pengaruh balai lelang ini terkait dengan tugas-tugas yang dilaksanakan pada proses pralelang, antara lain meningkatkan kualitas serta ikut memasarkan barang yang akan dilelang dengan cara-cara efektif, terarah, dan pengemasan yang lebih menarik.

3. Selain itu pihak kreditor sebagai pemohon lelang sebaiknya mempertimbangkan menggunakan cara penawaran lelang melalui internet pada proses lelangnya, hal ini sesuai hasil penelitian ini dengan memilih cara penawaran lelang melalui internet berpengaruh positif terhadap keberhasilan lelang. Proses penawaran melalui internet yang lebih efisien dan efektif dapat menyebabkan kompetisi yang tinggi karena mudahnya akses dan data lelang yang cepat didapatkan. Lelang melalui internet mengundang banyak penawar sehingga semakin banyaknya penawar maka kompetisi di antara para penawar akan semakin besar dan akan berpengaruh terhadap terjualnya aset yang dilelang.

4. Upaya-upaya lain yang dapat dilakukan untuk menarik peserta lelang sebanyak mungkin di setiap pelaksanaan lelang, antara lain. 
a. Penyebaran pengumuman lelang ke berbagai segmen pasar, baik melalui selebaran, surat kabar, penyebaran pengumuman lelang yang makin luas diharapkan dapat mencapai pasar yang lebih luas dan tepat sasaran.

b. Penyebarluasan informasi tentang properti riil yang dilelang juga dapat melibatkan aparat pemerintahan setempat (lurah/kepala desa), terutama untuk obyek lelang yang berlokasi di luar kota, karena umumnya pembeli obyek lelang yang berlokasi di luar kota adalah penduduk di mana properti riil obyek lelang tersebut berada.

c. Meningkatkan kerjasama dengan para pedagang dan agen properti riil, karena mereka memiliki pengalaman dalam hal jual beli propertiriil, memiliki hubungan dengan investor dan berbagai pihak di bidang properti. Adanya kerjasama ini diharapkan dapat lebih menyemarakkan lelang sehingga dapat menarik minat masyarakat pada umumnya untuk mengikuti lelang

5. Perlu terus ditingkatkan upaya untuk memasyarakatkan transaksi penjualan melalui lelang sebagai salah satu alternatif penjualan properti riil dan menciptakan image lelang yang baik. Upaya yang dapat dilakukan antara lain dengan memberikan pelayanan lelang yang baik, transparan dan cepat kepada penggunan jasa lelang (penjual, kreditur dan pembeli) sehingga masyarakat tertarik menggunakan jasa lelang sebagai alternatif untuk menjual atau membeli properti riil . Dengan semakin banyaknya masyarakat yang tertarik mengikuti lelang properti riil, maka pasar lelang akan menjadi bergairah. Hal ini tentunya akan meningkatkan frekuensi dan keberhasilan lelang yang pada akhirnya diharapkan dapat memberikan kontribusi bagi pengembalian hutang (debt recovery), dan di sisi lain akan meningkatkan penerimaan negara berupa Bea Lelang, PPh Pasal 25 maupun BPHTB.

6. Agar model penelitian yang diperoleh lebih sempurna, maka dapat dilakukan dengan memasukkan variabel-variabel lain, untuk menganalisa faktorfaktor yang mempengaruhi hasil lelang (OUT) karena konstanta model tersebut masih signifikan. Misalnya dengan menambahkan variabel kondisi pasar (SOM), posisi kekosongan (VP), kepemilikan (TENURE), penjualan terpaksa (DISTR), Jenis Properti (TYPE) dan waktu pelaksanaan lelang (DATE) sehingga dapat mempertinggi daya prediksi model.

\section{DAFTAR PUSTAKA}

Allen, M.T. dan J. Swisher, 2000, "An Analysis of the Price formation Process at a HUD Auction", Journal of Real Estate Research, 20 (3), 279-98.

Anglin, Paul M., 2003, The Value and Liquidity Effect of a Change in Market Condition, AREUEA Conference, Washington DC.

Arsyad. L., 1999. "Pengantar Perencanaan dan Pembangunan Ekonomi Daerah", BPFE Yogyakarta.

Bland, E.M., Black, G.S. dan Lawrimore, K., 2004, "Determinants of Effectiveness and Success for ebay Auctions", The Coastal Business Journal, 4 (1), 5-15.

Deboer, L., Conrad, J. dan McNamara, K., 1992, "Property Tax Auction Sales", Land Economics, 5 (3), 72-82

Departemen Keuangan RI, Keputusan Menteri Keuangan Nomor 466/KMK.01/2006 tentang Organisasi dan Tata Kerja Departemen Keuangan.

Eldred, Gary, 1987, Real Estate Analysis and Strategy, Harper \& Raw, New York

Fanning, Stephen F., Terry V. Grissom, and Thomas D. Pearson, 1994, Market 
Analysis for Valuation Appraisals, Appraisal Institute, Chicago.

Fisher, Jeffrey D. and Robert S. Martin, 1994, Income Property Valuation, Real Estate Education, Dearbon.

Gujarati, Damodar N., 2003, Basic Econometrics, $4^{\text {th }}$ Edition, Mc Graw Hill, New York.

Hidayati, Wahyu dan Budi Harjanto, 2003, "Konsep Dasar Penilaian Properti", BPFE, Yogyakarta.

Istina, 2009, "Determinan Tingkat Keberhasilan Lelang Eksekusi Hak Tanggungan di Kantor Pelayanan Kekayaan Negara Semarang Tahun 2005-2008”, Tesis S2, PPS- UGM, Yogyakarta (tidak dipublikasikan).

Kementerian Keuangan RI, Peraturan Menteri Keuangan Nomor : 27/PMK.06/2016 tentang Petunjuk Pelaksanaan Lelang.

160/PMK.06/2016 tentang Perubahan Peraturan Menteri Keuangan Nomor : 176/PMK.06/2010 tentang Balai Lelang.

Peraturan Menteri Keuangan Nomor : 90/PMK.06/2016 tentang Pedoman Pelaksanaan Lelang Dengan Penawaran Secara Tertulis Tanpa Kehadiran Peserta Lelang Melalui Internet.

Komite Penyusunan Standar Penilaian Indonesia (KPSPI), 2007, Standar Penilaian Indonesia 2007, MAPPI, Jakarta.

Marsono, 2006, "Susunan Dalam Satu Naskah UUD 1945 dengan PerubahanPerubahannya", Eko Jaya, Jakarta.

Mayer, C.J., 1998, “Assesing the Performance of Real Estate Auction”, Real Estate Economics, 26(1), 41-46.

Novrizal, 2007, "Faktor-faktor Yang Mempengaruhi Keberhasilan Lelang Eksekusi Hak Tanggungan Pada KP2LN Bandung II”, Tesis S-2, PPS- UGM, Yogyakarta (tidak dipublikasikan).

Ong, Seow E., Kenneth Lusht, and Chee Y. Mak, 2005, "Factors Influencing Auction Outcomes : Bidder Turnout, Auction Houses and Market Condition", Journal of Real Estate Reserch, Vol 27 No.2, 177-191.

Ong, Seow E., 2006, "Price Discovery in Real Estate Auction : The Story of Unsuccessful Attempts", Journal of Real Estate Research, Vol 28 No.1, 3959.

Ooi, Joseph T.L., C.F. Sirman, and Geoffrey K. Turnbull, 2005, "Price Formation Under Small Numbers Competition Evidence From Land Auctions in Singapore", Working Paper, No. 04-03, 1-22.

Setiawan, Nafiantoro Agus, 2005, "Analisa Faktor yang Mempengaruhi Hasil Lelang Property : Studi Kasus Lelang Eksekusi Panitia Urusan Piutan Negara (PUPN) di Kantor Pelayanan Piutang dan Lelang Negara (KP2LN) Jakarta II", Tesis S-2, PPS-UGM, Yogyakarta (tidak dipublikasikan).

Sekretariat Negara RI, Undang-Undang Nomor 4 Tahun 1996 tentang Hak Tanggungan Atas Tanah Beserta Benda Benda yang Berkaitan dengan Tanah, Tambahan Lembaran Negara Nomor 3632.

Sekretariat Negara RI, Vendu Reglement/Peraturan Lelang, ordonansi 28 Februari 1908 stb 08-189.

Sekretariat Negara RI, Vendu Instructie/Instruksi Lelang, Ordonansi 28 Februari 1908 stb 08-189.

Soesilo dan Pramudji R., 2007, Kitab Undang-Undang Hukum Perdata (Burgelijk Wetboek), Wacana Intelektual, Jakarta. 
Suprapno, 2006, "Karakteristik Real Property Jaminan Kredit yang Mempengaruhi Hasil Lelang: Studi Kasus Lelang Jaminan Kredit bank Badan Usaha Milik Negara/Daerah (Bank BUMN/D) pada Kantor Pelayanan Piutang dan Lelang Negara (KP2LN) Semarang", Tesis S-2, PPS-UGM, Yogyakarta (tidak dipublikasikan)

Tarigan, R, 2004, Perencanaan Pembangunan Wilayah, PT Bumi Aksara, Jakarta Widodo, Mohamad Arief, 2007, "Determinan Keberhasilan Lelang Eksekusi Hak Tanggungan di Kantor Pelayanan Kekayaan Negara dan Lelang Jakarta III Tahun 2005-2007”, Tesis S-2, PPS- UGM, Yogyakarta (tidak dipublikasikan). Widarjono, Agus, 2007, "Ekonometrika Teori dan Aplikasi Untuk Ekonomi dan Bisnis”, Edisi Kedua, Ekonisia, Yogyakarta.

Wan, W. dan Teo, H.H., 2001, "An Examination of Auctions Price Determinants on Ebay", The 9Yh European Conference on Information System. 1-11. 